\title{
Types of questions teachers use and their importance in the reading classes of English
}

\section{Daniela Gomes de Araúso Nóbrega}

Professora adjunto da Universidade Estadual da

Paraíba, e doutoranda do Programa de Pós-

Graduação em Letras e Lingüística da Universidade

Federal de Alagoas. Atua na área de Língua Inglesa,

principalmente nos seguintes temas: leitura, ensino/

aprendizagem, prática pedagógica, interação oral e

práticas discursivas na sala de aula.

ABSTRACT: This article proposes to analyze the teacher's questions in English as a Foreign Language reading classes of the secondary school to verify the extent to which they use the questions from an adequate way to instigate students' critical reading. As part of my MA dissertation about Reading studies in English, I attempted to describe the teachers' profile in Florianópolis public schools, Santa Catarina, in the reading instruction by the questioning perspective to discuss pedagogical implications in the questions asked by those teachers.

RESUMO:Este artigo propōe apresentar análise de perguntas dos professores de ensino secundário nas aulas de leitura em inglês como língua estrangeira para verificar até que ponto eles/elas usam as perguntas de forma adequada para instigar leitura crítica nos alunos. Como parte da minha dissertação de Mestrado sobre estudos de leitura em Inglês, eu procurei descrever o perfil dos professores de escola pública em Florianópolis, Santa Catarina, na instrução de leitura pela perspectiva de perguntas para discutir as implicaçōes pedagógicas nas perguntas feitas pelos professores.

Key-words: questions; reading instruction in English; teachers.

Palavras-chaves: perguntas; instrução de leitura em inglês; professores. 



\section{Introduction}

The idea for carrying out this study emerged from the researcher's awareness of the drawbacks English as a Foreign Language (EFL from now on) teachers usually face in reading classes at secondary education in Brazilian public schools. Observing mainly the pedagogical implications of the teachers' questions during the reading classes, I have found out that the instruction tends to be more textuallydriven due to the overemphasis on the study of vocabulary and grammar structures. Therefore, the aim of this article is to discuss what is behind the teacher's questions in the EFL reading classes as to see to what extent they are aware of the uses of appropriate questions to foster critical thinking to learners.

\section{Rationale}

One of the aspects of questioning behavior in the teaching of EFL reading is the use of display and referential questions, and the type of objective provided by them. Pearson and Johnson (1978) investigated whether teachers instruct their pupils to generate comprehension questions and concluded that "the issue is not whether or not use questions, but how, when and where they ought to be used" (p.154). As suggested by their taxonomy of questions, teachers should be conscious of when, how and where address textually explicit, textually implicit and scriptally implicit questions to the students, always bearing in mind that all these sorts of questions have the purposes to be pursued in the reading instruction.

Pearson and Johnson (1978) explain that textually explicit questions (also namely literal or display questions) are used to elicit learners' literal comprehension answers. For example, when pupils identify the age feature of some character from the text, this means that their answer came from the textually explicit questions. It serves only to confirm factual information provided by the text and does not assume the role of drawing inferences and predictions 
to interpret written texts. Yes/no questions constitute one of the examples of this question.

Some studies have been conducted as to visualize what teachers actually do with reference to the textbooks they manage. Oliveira (2000) investigated the extent to which "critical thinking is being fostered by question-asking in Portuguese reading comprehension texts for secondary students" (p.41). She discovered that reading comprehension textbooks usually explore textually explicit questioning probably due to "the political ideology of a country" (p.48). First, the teaching based on the traditional pedagogy to learning has given priority to the display of factual questions. There is more concern with the delivery of information instead of the learning itself, i.e. reading critically. Second, as a result of such behavior, there is more emphasis on the teachers' standpoint than of the learners'. Therefore, students tend to be motivated to expose answers that are in accordance with the text and the teachers' point of view.

Likewise Oliveira (2000), Coracine (1995) investigated the students' behavior in EFL lessons in reading classes and concluded that they seem to answer more what teachers require them to do. She contends that this behavior is the reflection of both teachers' and the textbooks' types of questions. And students, consequently, usually follow what teachers and textbooks require them to do. Coracine classifies the teachers' questions into two types: didactic and communicative. In the didactic, the students' voices primarily rely on the teachers' questions. For example, chain questions, multiple choices, gap completion, initiative and questions and answers by the teacher aim at cheering up the classes. They seem to develop a passive behavior on students since they don't provide room for reflection because the answers are mostly based on the text. However, the communicative ones seem to lean the students' voice both in terms of answers and content. Similar to daily questions, the communicative encourage discussions in class and teachers don't expect the students' 
answers to be correct. The instruction is devoted to the negotiation of meaning.

Different from the above question, the inferential ones normally foster critical thinking. Pearson and Johnson (1978) classify them of two sorts: textually implicit and scriptally implicit. The former "have answers that are on the page, but the answers are not so obvious" (p.57). That is, the questions and answers are textually derived but the relation between them is implicit forcing the reader to draw inferences based on a sequence of events found in the text. In turn, the latter are the ones that have their answers from the readers' background knowledge. Using their 'script' - term used by these authors instead of 'schema' - the students use their prior knowledge as a way to confirm or not their initial hypotheses about the text content.

In a study directed to middle school, junior high, secondary and postsecondary content areas, Ciardello (1998) proposes instruction based on cognitive and information processing research aiming at promoting students' questioning teaching. According to him, this teaching guides students to evolve cognitive (comprehension-fostered) and metacognitive (comprehension-monitoring) strategies in elaborating questions of their own interest. He names the cognitive questions as thinking operations used to explain, state logical relationships, to compare and contrast ideas in the text. The metacognitive strategies, on the other hand, serve to self-check whether the material was understood or not. In doing so, Ciardello believes that orienting students on how to produce "knowledge-seeking and hypothesisgenerated questions" (p.212) teachers are, thus, motivating students for critical reading. In other words, it will be the students' questions that lead them to make inferences, to capture the principal and secondary ideas as to interpret what they are reading meaningfully. 


\section{Method}

The data for this study was collected at Colégio de Aplicação of the Universidade Federal de Santa Catarina (UFSC) and Colégio Estadual Getúlio Vargas, in Florianópolis, Santa Catarina. The research was divided into two moments. First, twenty teachers were orally interviewed based on a thirteen-question questionnaire. Second, two out of these teachers were chosen as to observe their reading classes. The class observation was through note-taking having as a base the research questions used in the interview (see Appendix 1). The questions used in the interview served as a checklist to verify whether oral information given by teachers was covered or not in their EFL reading classes. A total of 12 hours of classes were observed from each teacher.

\section{Participants}

Twelve teachers from different public schools were chosen to take part of the first moment of the research. Eight out of twenty teachers taught at junior high school, the equivalent of the $5^{\text {th }}$ to the $8^{\text {th }}$ grades. And twelve out of twenty teachers taught at both junior high and high school; from the $1^{\text {st }}$ to $3^{\text {rd }}$ grades of the secondary education. For the class observation, teacher A was from "Colégio Aplicação" in which the $1^{\text {st }}, 2^{\text {nd }}$ and $3^{\text {rd }}$ levels of high school were analyzed. And teacher B was from "Colégio Estadual Getúlio Vargas" having the $7^{\text {th }}$ and $8^{\text {th }}$ levels of junior high school being investigated. The criteria for the selection of the two teachers were: a) availability to take part of the research; b) teaching reading at least twice a week; c) the teaching of one of the teachers should be more traditional on one hand, and the other more communicative, on the other hand; d) and the teachers had to teach in both junior high school and high school classes. 


\section{Teachers' interview}

The two questions that guided me to analyze the teachers' questioning behavior were of the number 10 and 11 of the questionnaire (see Appendix 1) which are 10) What sorts of questions are used in the reading instruction: inferential or literal? 11) What are these questions used for?

\begin{tabular}{|l|l|}
\hline Question types & Number of Teachers \\
\hline Literal & 4 \\
\hline Inferential & 5 \\
\hline Both questions & 11 \\
\hline
\end{tabular}

\begin{tabular}{|l|l|}
\hline Reasons to pose questions & Number of teachers \\
\hline To reflect in English & 4 \\
\hline $\begin{array}{l}\text { For students to give different } \\
\text { opinions }\end{array}$ & 1 \\
\hline To make students talk & 4 \\
\hline $\begin{array}{l}\text { To make a bridge with students } \\
\text { reality }\end{array}$ & 4 \\
\hline $\begin{array}{l}\text { To raise awareness about overall } \\
\text { compreliension }\end{array}$ & 1 \\
\hline To check the content of the text & 7 \\
\hline To help them understand the text & 1 \\
\hline No reply & 2 \\
\hline
\end{tabular}

Eleven out the twenty teachers informed that they pose both textually explicit and scriptally implicit questions. But they stated that they tend to focus more on the textually explicit, mainly in comprehension exercises, as to check out whether students understood the content of the text. The reasons to use scriptally questions are said as in, "I ask students to try to find the message behind the text"; "There are moments that I ask them to check text information and to give their own opinions"; "I use 
referential questions to make students talk" (my translation). The explanations for the use of textually explicit questions can be seen as in "I accept the answers that are right according to the text"; "I want students to check factual information"; Students have to check text information"; "Literal questions are used for students to complete the reading tasks" (my translation).

From the findings obtained, it appears that the majority of these teachers tend to believe that the text content has to be more discussed in detriment to the students' opinions toward the theme of the reading. As already observed by Coracini (1995), this view of questioning contribute not only for a passive behavior of the students, but also reinforce the ideology of the teachers' voice, i.e. it is what the text presents that should be considered, and it is based on the teachers' questions that the reading is conducted. Two teachers argued that, since they have no supporting structure to work with EFL reading, the text primarily functions to teach grammar and vocabulary.

Contrary to the previous view, five teachers reported that "inferential questions serve to warm-up the reading lessons" (my translation). They claimed that they can aid students understand that their background knowledge on the subject matter studied in class is the driving force to interpret what they are going to read. When they motivate students to do so, one of them stated, they emphasize the need for joining old (knowledge of the world) with new information found in texts as to construct their own meaning of the text. Texts are, therefore, used as a starting reference for the creation of different readings under the same topic. 


\section{Classroom Observation}

\section{Teacher A}

It could be noticed that what teacher A does in his/her reading class is not exactly what he/she said in the interview. This evidence corroborates what current EFL and ESP classroom research say about the topic (Amadeu-Sabino, 1994). For both General English and English for Specific Purposes (ESP) teachings, he found out that the teachers' discourse doesn't confirm their pedagogical praxis.

Teacher A's mostly used questions:

Textually explicit — 48

Scriptally implicit $\longrightarrow 07$

There were two types of question constructions applied. First, the yes/no questions such as 'were the animals in the film very common?', 'was the movie a love story?' and 'did Tony watch the film?' Some of the whquestions were 'what's AIDS?', 'what causes AIDS?', 'what's solidarity?' and 'how to be solidary?'

From classroom observation, findings have revealed that the textually explicit questions were more used particularly when he/she was explaining the reading exercise. Mostly used before the silent reading, whquestions were sometimes applied to elicit students' responses. In this case, these questions could be classified as scriptally implicit ones. During and after the reading, yes/no questions were more employed as to recall factual information from the written text. As could be observed, the answers provided by the students, mainly for the 'what's solidarity?' and 'what's AIDS?" questions, were explicitly stated in the text. Although the teacher A's praxis was aimed to foster the students' responses based on their prior knowledge, the students relied most on the text's voice to reply. 
During reading, teacher $\mathrm{A}$ tended to exploit textually explicit questions having two objectives in mind: check word meanings and text factual information. His/ her emphasis seemed to be strictly related to the content of the text resulting on the students' dependency on the teacher's voice to answer the questions. Here, what he/ she said on the interview seems to confirm his/her practice. Moreover, as noticed by Oliveira's (2000) and Coracini's (1995) findings, this sort of questioning behavior focuses on the teacher's viewpoint leaving students to only expose but not justify the questions. Consequently, the learners tend to assume a passive behavior toward the questions because they should answer what the teacher requires them to do.

\section{Teacher B}

Results showed that teacher B used scriptally implicit and textually implicit questions more than the textually explicit ones.

Teacher B's mostly used questions:

Textually explicit -34

Scriptally implicit $\longrightarrow 45$

Some of teacher B's questions are: "What's cleaning equipment?"; "Do you all have pets? What pets? How do you talk to them?" Do you like to read funny stories? Why?" and "What's the story about?"

As observed in the interview and in the classroom, teacher B attempted to encourage the students to engage in oral discussions before the reading by using the scriptally implicit questions. Either written on the board or orally said, these questions were applied in the pre-reading tasks, and their aims were twofold. First, they served to open discussion before reading. Second, they aimed at brainstorming students' hypothesis on the text content. The driving-force of this procedure, as pointed out by Ciardello (1998), was to make the students predict, hypothesize, 
infer, reconstruct, judge, defend and/or justify their points of view. These strategies could be identified throughout his/her reading classes as the students actively participated defending their view to one another.

The textually implicit questions used by the teacher served to fulfill one particular objective: to study grammar through the text. Usually applied after the students' silent reading and as part of post-reading activities, these questions' aim was to develop metacognitive (or comprehension-monitoring) strategies. In asking, "what does this phrasal verb mean here?", the teacher tried to call students' attention to link the phrasal verbs meanings with contextual clues provided by the text so that they could complete the reading tasks. Although dictionaries were permitted, inferring meanings through visual aids and context was the recurrent device managed by the teacher.

However, the questions were mostly managed by the teacher either to open the reading or after reading by the time students were required to complete the tasks. No student-generated questions were fostered. As suggested by Coracini (1995) and Ciardello (1998), student questioning aids students to monitor text comprehension since it involves summarizing and leads to independent learning. Although students' voice was crucial for the outset of the reading class, it seemed that the questions applied in post-reading tasks represent both the textbook and the teacher's voice.

It could be concluded that scriptally implicit questions before reading and textually explicit ones during and after reading were the most explored in teacher A's classes. Thus, the students tended to give factual information depending both on what was shown in the text and on the teacher's voice. On the contrary, teacher B's classes applied textually explicit and scriptally questions before, during and after reading aiming at joining the students' prior knowledge to the information encountered in the text. Orienting students to generate their own questions, nevertheless, seemed to be avoided by the teachers' practices. 


\section{Final Remarks}

This study of teachers' questioning behavior supports the view that questions should be carefully managed in reading classes since they reflect the teachers' way of looking at texts. As it was mentioned before, if teachers' questions emphasize literal comprehension in detriment to those which foster critical attitude toward the text content, students will believe that they have no place to state their own voice, i.e. own opinion.

The aim of this article was to show what actually happens in an EFL reading class as to discuss the teachers' pedagogical intentions through questioning. Contrary to what is proposed by Ciardello (1998) and Coracini (1995), the reading class reality still favors the teacher's voice not the students'. Although reading studies have revealed a need for developing critical thinking in students, teachers from Brazilian secondary education seem to insist that what is presented in the text is the unique source of information. One of the problems this belief, represented by the questions they pose, raise is that more and more students see themselves dependent on the teacher's voice as to interpret what they read. Helping learners to become more critical, leading them to question, to evaluate and to discuss, teachers may contribute to the formation of readers who are able to function well in society, exercising their citizenship. 


\section{References}

AMADEU-SABINO, M. O dizer e o fazer de um professor de LE em curso de Licenciatura: Foco na abordagem declarada comunicativa. Tese (Doutorado em Lingüística) UNICAMP, São Paulo, 1994.

CIARDELLO, A.V. Did you ask a good question today? Alternative and metacognitive strategies. Journal of Adolescent and Adult Literacy, vol.2, n.3, p. 210-319, 1998.

CORACINI, M. J. R. F. Leitura: decodificação: processo discursivo? In: CORACINI, Maria José. O jogo discursivo na aula de leitura, língua materna e língua estrangeira. São Paulo: Pontes, 1995, p. 13-20.

OLIVEIRA, S. Question-asking in Brazilian Portuguese reading comprehension textbooks. Ilha do Desterro, Florianópolis, v.38, p.39-56, jan./jun. 2000.

PEARSON P.D.; JOHNSON, P.D. Questions. In PEARSON P.D.; JOHNSON, P.D. Teaching reading comprehension. New York: Holt, Rinehart and Winston, 1978, p. 154-178. 


\section{Appendix - Teachers' Questionnaire}

Questionário dirigido aos professores de inglês da rede pública de ensino de Florianópolis, Santa Catarina.

1. Which grade do you teach?

2. How many hours of a week do you have with each group?

3. How many hours of a week do you teach reading in English?

4. Do you adopt any specific material? If so, what do you use? If not, where do you base your classes?

5. If you adopt a specific textbook, how much do you deviate from it? Do you include any extra material? If so, what exactly does this material include?

6. What are the methodological procedures used in the classroom? Describe all the steps you follow in the reading class.

7. What types of reading tasks do you apply to the texts used?

8. How are these activities organized?

9. What is emphasized in the reading classes?

10. What sorts of questions are used in the reading instruction: inferential (when answers are not explicitly stated in the texts) or literal (when answers are right there in the texts)?

11. What are these questions used for?

12. Is there any opportunity for participation and autonomy given to students during the classes? How is this actually accomplished in the classroom?

13. How is the evaluation of reading comprehension done? 